This is a self-archived - parallel published version of this article in the publication archive of the University of Vaasa. It might differ from the original.

\title{
Relationship Between Firm's Performance and Factors Involved in the Selection of Innovation Providers
}

Author(s): Zafar, Afnan; Kantola, Jussi

Title: $\quad$ Relationship Between Firm's Performance and Factors Involved in the Selection of Innovation Providers

Year: $\quad 2018$

Version: Final draft (post print, aam)

Copyright Springer International Publishing AG, part of Springer Nature 2019

Please cite the original version:

Ovaska, T., Niemi, S., Katila, T. \& Nilsson, O. (2018). Relationship Between Firm's Performance and Factors Involved in the Selection of Innovation Providers. In: Kantola J., Nazir S., Barath T. (eds) Advances in Human Factors, Business Management and Society. AHFE 2018. Advances in Intelligent Systems and Computing, vol 783, 1682-1683. https://doi.org/10.1007/978-3-319-94709-9_20 


\title{
Relationship between firm's performance and factors involved in the selection of innovation providers
}

\author{
Afnan Zafar ${ }^{1,}$ Jussi Kantola ${ }^{1}$ \\ ${ }^{1}$ School of Technology and Innovations, University of Vaasa, Wolffintie 34, 65200, Vaasa, \\ Finland \\ \{Afnan.Zafar, Jussi.Kantola\}@uva.fi
}

\begin{abstract}
Innovation is the backbone of the product development in present era for the survival of the corporate organization in the respective market. Changing trends in every passing day are making the product development more competitive and innovative. This paper investigates the relationship between firm's performance with respect to outsourcing innovations and factors affecting the selection of contract research organizations or innovation providers. The research is conducted by a self-designed instrument in the form of a survey form on 112 respondents internationally in 17 countries. The paper will give empirical relationship among firm's performance, outsourcing innovations and six major factors, which play a vital role in the selection of CROs. Proposed hypotheses in this article are based on empirical relationship, which is validated by SPSS 24 . The findings support the conceptual model and offer many managerial implications, which are described in detail at the end of the paper.
\end{abstract}

Keywords: Innovations, firm's performance, contract research organizations, outsourcing

\section{Introduction}

The dynamics of product development industry has been changing with rapid pace according to recent reviews of the international business, management, and innovations. Every research-based company wants to compete in a market with unique innovations. To be successful in this competitive environment companies are outsourcing innovations. Although some researchers have paid attention to risks of outsourcing innovations [1], little is known about the impact of outsourcing innovations on firms performance. Some research has been carried out to measure the relationship of firm performance and CROs they engaged.

Firm's performance has typically been measured based many other parameters such as marketing, sales, management, human resource, and production. The literature of firm's performance based on these parameters is very rich [2]. However, the previous researcher has not focused on the impact of outsourcing on the performance [3], especially when we talk about outsourcing core and unique skills. Some studies show that innovations should not be outsourced [1]. One of the reasons for unavailability of such measurement might be because measuring the firm's performance based on 
outsourcing innovations is different from other conventional ways and different tools may be required to measure this relationship. Researchers have discussed innovation performance [4] but very few have addressed phenomenon empirically [5]. A major point of difference between measuring firm's performance based on production, management, marketing, sales in comparison to innovation-based measurement is that innovations always decide the future of performance of the new product in the market, which directly impacts overall firm performance in the market [6].

Moreover, in recent past companies are outsourcing innovations from other companies or contract research organizations (CROs) [7]. As a result, the parent company's performance is not only related to innovations but also to the innovation provider's performance and quality of innovation they provide to parent company [8]. Thus, outsourcing innovations play a vital role when we measure firm's performance, which is intensely dependent on such innovations and CROs. That is, outsourcing innovation involvement in the overall process is very useful and critical while measuring the performance of such organizations [8]. Past research on measuring firm performance only revolves around following broad issues: Firms performance based on quality and quantity of production rate, managing the overall firm, level of marketing and sales and human resources impact [9].

This research attempts to examine the relationship of firm's performance with outsourcing innovations and ties CROs while measuring the performance of parent company. Essentially, this paper responds to the call for the new thinking about measuring R\&D based firm's performance and draw inspiration from the work of Chesbrough and Crowther 2006 [9]. They stressed the need for outsourcing innovations, open innovation paradigm, the primary concepts employed in this process and challenges faced by firms while adopting this whole process [9]. Additionally, the research has focused on the business-to-business process because outsourcing innovations and open innovations are in numerous number in the form of business-to-business partnerships in the modern economy but are not intensively researched.

The main research question driving this study is as follows:

"Does factor affecting the selection of outsourcing provider effect performance of outsourcing"

We have included six factors namely reputation of innovation provider, the flexibility of innovation provider, technological resources of provider, past relationship with the provider, policy of provider about intellectual property rights and cost-effectiveness of the provider. The findings of this research are expected to provide guidelines to the firms that are extensively using outsourcing innovations and CROs for their business. The paper has four parts. First part reviews the existent literature relevant to outsourcing innovations, open innovations, CROs and their relation to firm performance. The paper then represents data collection methods, research instrument description, data analysis techniques and overall research methodology. After that, findings are described and summarized. The paper concludes with the relationship of factors affecting in the selection of CROs or innovations provider with firm's performance, and discuss theoretical and managerial implications and directions for further research. 


\section{Research Background}

The concept of firm performance based on innovations is not very new. In the past, this concept was studied in the broader picture and with general understanding. It was studied with reference to firm policies and creative ideas within the firm. During this process companies also analyzed their innovative products and firm performance together in different markets [10]. After the 1980s all the international markets became very competitive and companies started to look for partners to improve the overall productivity. Another challenge in this competitive environment was to make partnerships with innovative companies [11]. All this environment collectively leads towards outsourcing innovations by firms.

The outsourced innovations, directly and indirectly, started to play their role in overall firm performance. The firm performance is a broad area and extensive research is already being done, based on traditional factors. The firm performance was measured mainly using financial ratios, based on supply chain collaborations, decision-making, information technology, human capital, intrapreneurship culture, customer relationship management, intellectual capital, and leadership. Different tools and patterns were used to evaluate firm performance based on these parameters described earlier [12].

The innovation impact on firm performance was studied based on the type of innovation involved in each scenario. These include the impact of four types of innovations on firm performance which were a product, process, marketing and organizational innovation [13]. Another determining factor in recent studies was the scale of innovation activity and its economic impact [14]. Few other studies showed that the relationship between the specific type of innovation and its direct effects on firm performance [15].

The concept of innovation moved further from the introduction of newness in the market towards its active role in firm's performance. Outsourced innovations started to play a vital role for competitive advantage for the firms. This has not only helped the firms to grow from their competitors, but it also started to impact the countries. Higher the number of innovative firms in a country more and more growth of country's economy was observed [16]. However, this environment started to move towards saturation. Partnerships and sharing innovations did not remain that simple anymore. Selecting an innovative partner for a company is becoming a dilemma for all companies [1].

Several factors play vital roles in the selection of the outsourcing firm. Each firm requires different levels of innovations thus there can be various factors which possibly be considered while the selection of innovation provider. While doing the collaborations with outsourcing provider parent companies look in to different factors such as, how the provider can help them to take competitive advantage of market opportunities, technological expertise of future partner firm, level of responsiveness of the provider to changes in market, time improvement factor for their future innovative products, cost-effectiveness in comparison to in-house innovations and quick entry into new markets [17]. Even firms are focusing a lot on different factors but still, according to some estimates, $70 \%$ of such partnerships fail [18].

Nevertheless, the literature shows that there can possibly be six major factors which are connected to the selection of innovation providers one way or another. These factors include reputation of innovation provider, the flexibility of innovation provider, technological resources of provider, past relationship with the provider, policy about intellectual property rights (IPRs) of provider and cost-effectiveness of the provider. 
This article discusses relationship among these six factors, associated with selection innovations providers, and the performance of the firm.

\section{$3 \quad$ Research Framework and Hypotheses}

When firms make a partnership with innovation providers, firm's performance is not only dependent on the innovative idea that they are trying to outsource but also is directly dependent on their relationship with innovation providers. There are many factors which play a vital role in the selection of innovation providers named earlier, but this paper investigates six main factors which are involved in all types of open innovation contracts and their relationship with overall firm performance.

H1. Firm performance measurement is based on many parameters from different angles as described earlier [12], however, the recent literature does not give any explicit relationship between firm performance and reputation of innovation providers in the industry. But, there were very few specific studies and the relationship had been studied between the strategic orientations of a parent company with respect to the selection of cross-border outsourcing partners for acquiring knowledge. The study emphasized to give maximum attention while doing such knowledge attainment [19].

Hypothesis 1: There is positive relationship between firm performance and reputation of innovation provider in the industry in terms of $R \& D$

H2. Few studies measure the supply chain and supply chain management flexibility in general and their relationship with performance outcomes in manufacturing firms [20]. Keeping in view the previous literature that within a firm flexibility mostly increase the performance of the firm, therefore it is expected that there must be similar relationship while firm does a partnership with outsourcing providers [21].

Hypothesis 2: There is a positive relationship between firm performance and flexibility of the innovation provider.

H3. While outsourcing from a third party the main purpose is to attain the best innovative and updated technology available. So, the strength of technological resources of the innovation provider always has key importance. Some studies are available which had measured the impact of the external expert organization on firm's own R\&D [22] but still, there is no specific study which measures the relationship and its extent between firm's performance and provider's technological resources.

Hypothesis 3: There is positive relationship between firm performance and provider's latest technological resources

H4. There is strong evidence regarding business to consumer (B2C) healthy relationship impact on firm's overall performance [23]. But when we talk about the healthy relationship of one firm to another firm while providing R\&D services, not many direct studies available for such relationship and its impact. Few studies are available with reference to supply chain collaboration and their impact on firm performance [24].

Hypothesis 4: There is a positive relationship between firm performance and innovation provider's long-term working relationship with hiring firm.

H5. The intellectual property rights (IPRs) is getting high importance especially firms involving open innovation process [25]. But it is not necessary that both partnering firms always have the same level of values or standard operating procedures (SPOs) to 
handle intellectual property. This directly impacts the firm's performance in long run or sometimes in the middle of the collaborative project. Thus,

Hypothesis 5: There is a positive relationship between firm performance and strictness of provider's policy for intellectual property rights (IPRs).

H6. Literature pointed out about the relationship between firm's performance and selection of cost-effective partners. Many studies concluded a direct relationship between these two [26]. But all studies had different environmental factors which had played a vital role while testing this relationship. Assuming the similar relationship, this paper also hypothesizes about the positive relationship between these two.

Hypothesis 6: There is a positive relationship between firm performance and provider's cost-effectiveness in industry.

All hypotheses are represented in the following Fig. 1.

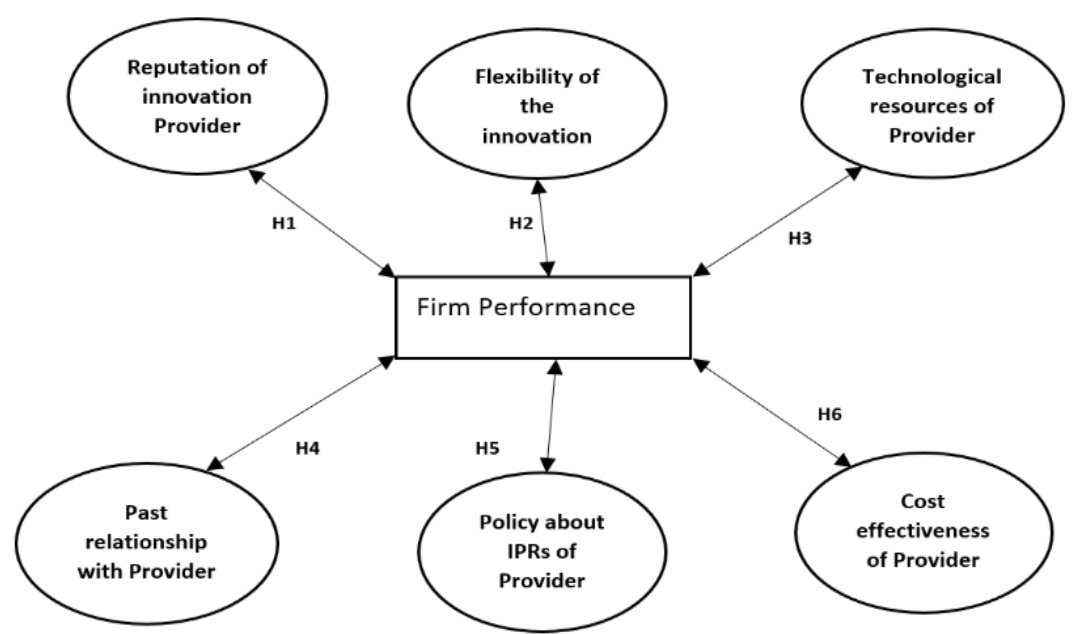

Fig. 1. Research framework and hypotheses

\section{$4 \quad$ Methodology}

The target population for this study consisted of professionals (Managers, Scientists, and Developers), all of them have immediate experience in outsourcing innovations or somehow associated with the specific segment of R\&D in respective firms. The participated individuals were from 17 different countries across the globe. Approximately 60 companies were involved in this survey. The survey is conducted in 2016-2017 approximately in the one-year time frame. The unit of analysis was individual professional. The sampling frame was randomly selected, 260 professionals. The professionals were working in countries such as Finland, Sweden, Denmark, USA, Canada, Germany, UK, Cyprus, Singapore, UAE, KSA, Oman, Netherlands, Malaysia, Pakistan, and India. The selection criteria were related to the dependency of the firm on outsourcing innovations for their product development. 
The industrial segments involved in this research was distributed among the sectors such as pharmaceutical industry $(42 \%)$, ICT industry $(20 \%)$, life sciences $(6 \%)$, Engineering services $(11 \%)$, financial services $(6 \%)$, robotics $(3 \%)$, logistics $(3 \%)$, telecommunication $(2 \%)$, chemical industry $(5 \%)$ and automotive industry $(2 \%)$. Concurrently face-to-face interviews were also arranged, mainly the selection of candidates was dependent on their strong profiles, availability for interview and their key position in the organization. Appointments were requested by phone and official emails with an offer letter for participation in research and privacy policy. Interviews were conducted by the corresponding author. Few interviews were also conducted on phone. Survey forms were given to interviewees and questions were asked in the same order.

The final realized sample consisted of 112 usable questionnaires, representing a $43 \%$ response rate. All 112 responses were analyzed. The firm's revenues who participated in the survey were varied largely between less than 1 million USD to more than 10 Billion USD in 2015-2017, the main reason of this variation was involvement of various demographic areas in research due to local currency values at the time of the survey. The questions were also asked about profiles of respondents who participated in the study. Approximately 39\% of respondents had more than 10 years of experience, $26 \%$ had more than 6 years up 10 years of experience while $31 \%$ having 1 to 5 years of overall experience in the respective industry.

The initial survey form was pre-tested with a convenience sample of 10 researchers involved in similar kind of working fields, using the collaborative participant pre-testing method explained by Cooper and Schindler [27]. Data for the actual study was collected in approximately one-year time from February 2016 to April 2017. Some of the reasons behind the longer duration of data collection were that it was collected from many countries and in many cases, respondents need permission from higher management before participation in research. Google forms were used for the survey but in some cases, respondents preferred hard copies of survey forms by mail or in person. Two weeks after initial contact with suitable respondent, follow up reminders were also sent. No incentives were given to respondents to participate in the survey. All the data was confidentially handled, and no names will be revealed due to each company's privacy policy except those who allowed revealing their names. The questions involved in this survey were seven-point Likert scale statements. All the scale points of these questions were labeled ranging from 1 (Strongly disagree) to 7

(Strongly agree).

These questions and respective options were designed, keeping in view the open innovation concept described by Chesbrough [9]. The question was asked, "Outsourcing innovations in product development process leads to increase in firm's performance". Another question was asked "What are the most important factors in my view (respondent's view) while the selection of contract research organization (CROs) or outsourcing providers" The answer to this question was in the form of six different options, respondents had chosen as many as they wanted to choose or at least one of them. Answers to the questions were scaled on Likert's scale as described earlier.

The empirical analysis is performed between firm performance and all the six factors to find out how significantly each factor related to firm's performance. The answers given by the respondents acted as variables in the hypotheses developed in this paper and tested statistically against each other to measure the correlation significance and 
later firm performance. The similar research approach is done as of Gunday et al. [13], but in their research, they measured the firm performance with respect to the innovativeness of firm, but in this current study, firm performance is measured based on the factors affecting the selection of innovation providers or CROs. So, to summarize the method, analyzing the performance of the firm with respect to factors acquiring open innovation is the main scope of the method.

\section{$5 \quad$ Analysis and Findings}

The data was collected from ten industrial segments as described earlier with the help of self-designed research instrument. To test the hypothesis the correlation analysis was performed using SPSS 24. Three of the hypotheses are validated by the empirical analysis while on the other hand three of them are not statistically significant. Table. 1 shows all the six hypotheses (H1 to H6). The first hypothesis (H1) claimed that firm performance directly dependent on the reputation of the innovation provider, but the statistical analysis shows that there is non-significant $(p>0.05)$ relationship exists between these two. The second hypothesis $(\mathrm{H} 2)$ is validated as it is statistically significant $(p<0.05)$ relationship between firm performance and flexibility of innovation provider. Third and fourth hypotheses (H3, H4) also validated because it is significant $(p<0.01)$ relationship between firm performance and quality of technological resources and longterm past relationship with innovation provider. Hypotheses 5 and 6 are not validated because of non-significant $(p>0.05)$ relationship between firm performance and policy of innovation provider about intellectual property rights and cost-effectiveness of innovation provider.

Table 1. Correlation analysis

\begin{tabular}{|c|c|c|c|c|}
\hline $\begin{array}{l}\text { Hypothe- } \\
\text { ses }\end{array}$ & Factors & $\begin{array}{l}\text { Correla- } \\
\text { tion } \\
\text { signifi- } \\
\text { cance }\end{array}$ & $p$-Value & Result \\
\hline $\mathrm{H} 1$ & $\begin{array}{l}\text { Reputation of } \\
\text { innovation } \\
\text { Provider }\end{array}$ & 0.122 & $p>0.05$ & Not supported \\
\hline $\mathrm{H} 2$ & $\begin{array}{l}\text { The flexibility } \\
\text { of the innovation } \\
\text { Provider. }\end{array}$ & $0.034 *$ & $p<0.05$ & Supported \\
\hline $\mathrm{H} 3$ & $\begin{array}{l}\text { Technological } \\
\text { resources Pro- } \\
\text { vider }\end{array}$ & $0.004 *$ & $p<0.01$ & Supported \\
\hline $\mathrm{H} 4$ & $\begin{array}{c}\text { Past relation- } \\
\text { ship with Provider }\end{array}$ & $0.009 *$ & $p<0.01$ & Supported \\
\hline H5 & $\begin{array}{c}\text { Policy about } \\
\text { IPRs of Provider }\end{array}$ & 0.252 & $\begin{array}{l}p>0.05 \\
p>0.05\end{array}$ & Not supported \\
\hline
\end{tabular}


H6

Cost-

effectiveness of

Provider

** Correlation is significant at 0.01 level

* Correlation is significant at 0.05 level

Table. 1 shows the clear findings of the statistical analysis performed on collected data. It shows that Hypotheses H1, H5, and H6 are not supported while Hypotheses $\mathrm{H} 2, \mathrm{H} 3$, and H4 are supported. Findings expose that firm performance is positively affected by Flexibility, technological resources and past relation of innovation provider. But on the other hand, reputation, policy about IPRs and cost-effectiveness of innovation provider have no direct impact on firm's performance.

\section{Discussion and Conclusion}

This study investigates the potential relationship between firm performance and six major factors which play a key role while selecting an innovation provider partner. To our best knowledge that is the first study of this type which specifically deals with these factors in an open innovation environment. The results indicate that firm performance is positively related to three factors, on the other hand, it does not depend on other three factors while making a partnership with innovation providers. Three positively related factors are in line with previous studies related to firm performance [19], but other three factors have given different prospects as compared to previous studies.

The results are less clear with respect to the reputation of innovation provider, the policy of innovation provider about IPRs and cost-effectiveness of innovation provider. But these factors give us new prospects about partnering with innovation providers rather than focusing on traditional ones. The factor that was believed strongly in previous literature [26] that firm performance is somehow directly dependent on the cost-effective partners, is not validated by this research. The participants of the survey do not believe in the fact that cheaper the services or innovative processes provided by their partners more will be the firm performance. Similarly, respondents also believe in the fact that previous reputation of innovation provider and policy about IPRs are not crucial factors which can be related to firm's high growth. This is because they strongly believe in the quality of the innovation provided by their partners. The highly significant values in the remaining three factors validated that fact. The inconsistency in the validation of $\mathrm{H} 1, \mathrm{H} 5$, and $\mathrm{H} 6$ might be explained by the fact that all the six factors were put together during same survey and interviews. The respondents preferred $\mathrm{H} 2, \mathrm{H} 3$, and $\mathrm{H} 4$ in comparison to other three $(\mathrm{H} 1, \mathrm{H} 5, \mathrm{H} 6)$. It seems that these three factors are more important for them as being highly active innovative R\&D professional in the industry. The disagreement with the cost-effective factor [26] is one of the most noticeable things in this research. The relationship between firm performance and reputation of innovation provider also does not statistically significant. The most probable explanation of this non-significance is ever changing in dynamic market of innovation providers. 
Sometimes in past companies do not have good experience with one provider but the later same provider can shock them with remarkable innovation and their improved service.

The explanation behind IPRs inconsistency might be the thought that parent company's strong policy regarding IPRs should protect information leakage. They should make such partnership in which they are highly protected from their end and they know very well which information must share with their partner and when. Limiting the information sharing and designing of contract mostly in the hands of the parent firm which is going to outsource innovation.

In general, the results of this research indicate that flexibility of provider, technological resources and past relationship with a provider has a highly significant relationship with firm performance. This makes clear that although there are inconsistencies exist in above-explained three factors but the inclination of respondents towards remaining three factors show the current approach of respondents at the time of research. Moreover, current study empirically validates important factors related to the business-tobusiness context in the bigger picture. Business-to-business previous research was conducted on many factors, but there is no specific research available testing this type correlation between firm performance and these six factors described above. The best possible reason for a non-significant relationship in IPRs case is that all the functional innovation providers in the market follow the country-specific IPRs by default.

Consequently, the paper also reveals that the factors which were center of attention in last decade are not anymore very important for professionals or scientists involved in such contracting today. There are many new variables and factors involved with a high significance which in many respondents' opinion are more favorable and important now. Examples of such factors are quality of technological resources of provider, past relationship with innovation provider and flexibility of the provider. The past studies indicate that cost-effectiveness might be an important factor in general business-tobusiness partnerships based on transaction cost theory (TCT) [28]. However, when we talk about this specific partnership which, involves outsourcing innovation and new technologies in a cost-effective way, does not give guaranteed firm growth both in short run and longer terms. As a result, the managers involved in the selection of partner companies or innovation provider should be more focused on the quality of technology or innovation they are going to get from the provider and overall relationship. Managers and scientists involved in this process need to be trained and motivated in this rapidly changing outsourcing innovation industry.

In addition, several studies and researchers warned [21] about the flexibility factor as an important factor to consider while doing cooperation. This study also validates that factor and its significant relation to firm performance. Managers and scientists need to be vigilant enough about the fact that if the provider is not flexible enough it can cause serious problems in outsourcing innovations in the long run. Nevertheless, the past relationship with innovation provider cannot be ignored for making new partnerships. The reason behind this factor is that if there is successful innovation outsourcing has been done previously with some provider, it can be good decision to consider them in next project as both partners have a good understanding of each other's working environment. These findings support the conceptual model and offer many managerial implications. However, a certain or maybe bit longer time might be needed to study longterm implications of these factors while selecting the innovation provider. This is the 
reason many managers complained in other studies that such cooperation varied a lot case to case [29].

\section{$7 \quad$ Limitations and direction of future research}

Some limitations might be due to collecting data and interpreting results. The first limitation might be demographics of data set. For example, data were collected from 17 different countries at the same time in which developing, and highly developed countries were included in the same dataset. Although, many developed countries are outsourcing innovations from developing countries and vice versa still there is a huge difference in working culture. There is another potential reason for inconsistency due to common method bias. The study used a single questionnaire to measure all factors and patterns. So perhaps the significance of relationships in different factors and firm performance may be somewhat inflated.

The third potential limitation is related to the fact respondents involved in this survey have vast experiences of both sides of the working environment. It means that they have experience with parent companies and with outsourcing providers during their overall experience in the industry. They tried their best to answer the questions according to best of their experience and knowledge, but the fact is that both prospects are widely different when we do the analysis. The research approach in this study was very specific overall. It would then possible that these recognized shortcomings could inspire researchers to define their prospects with similar research agendas.

\section{References}

[1] A. Heocht and P. Trott, "Innovation risks of strategic outsourcing," Technovation, ELSEVIER, vol. 26, no. 5-6, pp. 672-681, 2006.

[2] M. A. Huselid, S. E. Jackson and R. S. Schuler, "Technical and Strategic Human Resources Management Effectiveness as Determinants of Firm Performance," Academy of Management Journal, vol. 40, no. 1, pp. 171-188, 1997.

[3] D. M. Gann and A. J. Salter, "Innovation in project-based, service-enhanced firms: the construction of complex products and systems," Research Policy, vol. 29, no. 7-8, pp. 955-972, 2000.

[4] K. Laursen and A. Salter, "Open for innovation: the role of openness in explaining innovation performance among U.K. manufacturing firms," Strategic Management Journal, vol. 27, no. 2, pp. 131-150, 2005.

[5] B. Cassiman and R. Veugelers, "In Search of Complementarity in Innovation Strategy: Internal R\&D and External Knowledge Acquisition," Management Science, vol. 52, no. 1, pp. 68-82, 2006.

[6] K.-P. Hung and C. Chou, "The impact of open innovation on firm performance: The moderating effects of internal R\&D and environmental turbulence," Technovation, vol. 33, no. 10-11, pp. 368-380, 2013. 
[7] A. Y. Lewin, S. Massini, and C. Peeters, "Why are companies offshoring innovation? The emerging global race for talent," Journal of International Business Studies, vol. 40, no. 6, pp. 901-925, 2009.

[8] U. Lichtenthaler, "Outbound open innovation and its effect on firm performance: examining environmental influences," $R \& D$ Management, vol. 39, no. 4, pp. 317-330, 2009.

[9] H. Chesbrough and A. K. Crowther, "Beyond high tech: early adopters of open innovation in other industries," $R \& D$ Management, vol. 36, no. 3, pp. 229-236, 2006.

[10] H. H. Stevenson and . J. C. Jarillo, "A Paradigm of Entrepreneurship: Entrepreneurial Management," Strategic Management Journal, vol. 11, no. Corporate Entrepreneurship , pp. 17-27, 1990.

[11] J. H. Dyer and H. Singh, "The Relational View: Cooperative Strategy and Sources of Interorganizational Competitive Advantage," Academy of Management Review, vol. 23, no. 4, pp. 660-679, 1998.

[12] J. Bonomi Santos and L. A. Ledur Brito, "Toward a Subjective Measurement Model for Firm Performance," Brazilian Administration Review, vol. 9, no. 6, pp. 95-117, 2012.

[13] G. Gunday, G. Ulusoy, K. Kilic and L. Alpkan, "Effects of innovation types on firm performance," Int. J. Production Economics, no. 133, pp. 662-676, 2011.

[14] "OECD Oslo Manual: Guidelines for Collecting and Interpreting Innovation Data," 3rd Edition, 2005.

[15] Z. Jin, N. Hewitt-Dundas and. N. J. Th, "Innovativeness and performance: evidence from manufacturing sectors," Journal of Strategic Marketing, vol. 12, no. 4, pp. 255-266, 2004.

[16] J. Fagerberg, D. C. Mowery and R. R. Nelson, The Oxford Handbook of Innovation, Newyork, USA: Oxford University Press, 2005.

[17] D. Littler, F. Leverick, and M. Bruce, "Factors Affecting the Process of Collaborative Product Development: A Study of UK Manufacturers of Information and Communications Technology Products," The Journal of Product Innovation Management, vol. 12, no. 1, pp. 16-32, 1995.

[18] E. Sivadas and F. R. Dwyer, "An Examination of Organizational Factors Influencing New Product Success in Internal and Alliance-Based Processes," Journal of Marketing, vol. 64, no. 1, pp. 31-49, 2000.

[19] Y. Li, Z. Wei and Y. Liu, "Strategic Orientations, Knowledge Acquisition, and Firm Performance: The Perspective of the Vendor in Cross-Border Outsourcing," Journal of Management Studies, vol. 47, no. 8, pp. 1457-1482, 2010 .

[20] Y. Liao, P. Hong and S. Rao, "SUPPLY MANAGEMENT, SUPPLY FLEXIBILITY AND PERFORMANCE OUTCOMES: AN EMPIRICAL INVESTIGATION OF MANUFACTURING FIRMS," Journal of Supply Chain Management, vol. 46, no. 3, pp. 6-22, 2010. 
[21] C. Camisón and A. V. López, "An examination of the relationship between manufacturing flexibility and firm performance: The mediating role of innovation," International Journal of Operations \& Production Management, vol. 30, no. 8, pp. 853-878, 2010.

[22] R. C.M. Yam, W. Lo, E. P.Y. Tang and A. K.W. Lau, "Analysis of sources of innovation, technological innovation capabilities, and performance: An empirical study of Hong Kong manufacturing industries," Research Policy, vol. 40, no. 3, pp. 391-402, 2011.

[23] T. Coltman, T. M Devinney and D. F Midgley, "Customer relationship management and firm performance," Journal of Information Technology, vol. 26, no. 3, pp. 205-219, 2011.

[24] M. Cao and Q. Zhang, "Supply chain collaboration: the Impact on the collaborative advantage and firm performance," Journal of Operations Management, vol. 29, no. 3, pp. 163-180, 2010.

[25] H. Candelin-Palmqvist, B. Sandberg, and U.-M. Mylly, "Intellectual property rights in innovation management research: A review," Technovation, vol. 32, no. 9-10, pp. 502-512, 2012.

[26] D. J. Teece, "Business Models, Business Strategy and Innovation," Long Range Planning, vol. 43, no. 2-3, pp. 172-194, 2010.

[27] D. R. Cooper and P. S. Schindler, Business Research Methods, McGraw. Hill International Edition, 2006.

[28] C. Yang, J. G. Wacker and C. Sheu, "What makes outsourcing effective? A transaction-cost economics analysis," International Journal of Production Research, vol. 50, no. 16, pp. 4462-4476, 2011.

[29] J. Vega-Jurado, A. Gutierrez-Gracia, I. Fernandez-de-Lucio and L. Manjarres-Henríquez, "The effect of external and internal factors on firms' product innovation," Research Policy, vol. 37, no. 4, pp. 616-632, 2008.

[30] I. Mc Carthy and A. Anagnostou, "The impact of outsourcing on the transaction costs and boundaries of manufacturing," International Journal of Production Economics, vol. 88, no. 1, pp. 61-71, 2004.

[31] P. Frankelius, "Questioning two myths in innovation literature," Journal of High Technology Management Research, vol. 20, pp. 40-51, 2009.

[32] H. Chesbrough and M. Bogers, "Explicating Open Innovation: Clarifying an Emerging Paradigm for Understanding Innovation," New frontiers in open innovation, no. In H. Chesbrough, W. Vanhaverbeke, \& J. West (Eds.), pp. 324, 2014.

[33] P. J. Richard, T. M. Devinney, G. S. Yip and G. Johnson, "Measuring Organizational Performance: Towards Methodological Best Practice," Journal of Management, vol. 35, no. 3, pp. 718-804, 2009. 